\title{
CUSTOMARY LAW IN INVESTMENT REGULATION
}

\author{
JORGE E. VIÑUALES*
}

\begin{abstract}
This article explores the expression of State sovereignty through customary norms in a regulatory space dominated by investment treaties. It argues that, because most of the actionable concepts expressing sovereignty in international law are general (not specific to a "branch") and customary, misunderstanding the role of customary law in investment regulation amounts to confining sovereignty to a few narrow carve-outs and exceptions in investment treaties. However, customary concepts operate autonomously and in parallel to treaties, unless specifically excluded by the latter. The lex specialis principle does not necessarily command the exclusion in toto of relevant customary rules. The article discusses the work of the Institut de Droit International in this regard and then analyses the investment case law relating to the application of the police powers doctrine, necessity, countermeasures and transnational public policy. It shows that failure to address specifically the articulation of treaty and customary norms even in the event the former apply as lex specialis is subtly eroding, without clear legal grounds, the customary expression of sovereignty in foreign investment disputes.
\end{abstract}

Keywords: customary law; bilateral investment treaties; sovereignty; Institut de Droit International; police powers doctrine; necessity; doctrine of countermeasures; transnational public policy.

\section{INTRODUCTION}

One peculiar feature of the body of scholarship on international investment law and arbitration is that, despite the considerable amount of published material, some major questions remain underexplored. In this context, the 2013 Resolution of the Institut de Droit International (IDI) on the Legal Aspects of Recourse to Arbitration by an Investor against the Authorities of the Host State under Inter-State Treaties ${ }^{1}$ is very welcome, as it identifies, for \footnotetext{
Kingdom.

${ }^{1}$ Legal Aspects of Recourse to Arbitration by an Investor against the Authorities of the Host State under Inter-State Treaties, Resolution of 13 September 2013, Tokyo Session ("Resolution"); Legal Aspects of Recourse to Arbitration by an Investor against the Authorities of the Host State under Inter-State Treaties, Report of A. Giardina, $18^{\text {th }}$ Commission, Yearbook of the Institute of International Law, Tokyo Session 2013 Draft Works ("Report"); Legal Aspects of Recourse to Arbitration by an Investor against the Authorities of the Host State under Inter-State Treaties, Travaux préparatoires, $18^{\text {th }}$ Commission (membership: Alexandrov, Audit, Bastid-Burdeau, Collins, Dominicé, El-Kosheri, Fadlallah, Lalive, Lankosz, Lowenfeld, Mayer, Orrego Vicuña, Ranjeva, Remiro Brotons, Ress, Schwebel, Subedi, Sucharitkul, Treves and Vinuesa), Yearbook of the Institute of International Law, Tokyo Session 2013 - Draft Works ("Travaux préparatoires") (this document consists of the deliberations of the Institut de Droit International (IDI) at the sessions of Naples (2009), Rhodes (2011), and the preparatory works for the Tokyo session, including the "Questionnaire" prepared by the
}

* Harold Samuel Professor of Law and Environmental Policy, University of Cambridge, United 
many highly debated issues, what the distinguished group of scholars composing the IDI see as a consensual solution. Yet, the Resolution has left several issues unresolved and others unexplored. The study of the main documents leading to this Resolution gives an external observer the impression that at least two reasons account for the remaining lacunae. One concerns the significant challenges involved in reaching a consensus on many issues. An indication of this is the increasingly narrow scope of the issues addressed as one moves from the initial to the final stages of the codification work. The other is perhaps more prosaic but no less significant for present purposes. Some questions were framed throughout the process from a perspective - that of special regimes - which has become so common that we tend to lose sight of what it fails to capture. My purpose in the next paragraphs is to discuss one issue that has received scant attention in investment law scholarship and which is, in my view, of great importance: the customary expression of sovereignty in international investment regulation.

The starting point of my analysis is a basic observation that I have tried to develop at some length elsewhere ${ }^{2}$ namely that many, if not most, of the legal concepts expressing sovereignty in international law are of a general and customary nature. Legal concepts such as permanent sovereignty over natural resources, ${ }^{3}$ immunities, ${ }^{4}$ the police powers doctrine, ${ }^{5}$ necessity $^{6}$ or some pro-sovereignty presumptions ${ }^{7}$ are applicable not only in the context of investment disputes but also more broadly in other contexts. Because sovereignty concerns all areas of international law, many of the legal concepts expressing it have a general (by contrast with a branch-specific) scope. As such, they are grounded on general international law and, more specifically, on customary norms. For this reason, analysing the relationship between investment treaties and customary international law is an important step for the understanding of the room for sovereignty in investment regulation. This basic and yet important point has been neglected, including by the work of the IDI. To be fair, although the Resolution does not make reference to this question, the interactions between investment treaties and customary international law were a major concern of the Rapporteur, and they were discussed to some extent at the $18^{\text {th }}$ Commission. Yet, the focus of the discussion was not on the customary

Rapporteur on 5 April and revised on 10 June 2013, as well as the answers received and discussions at the Rome meeting of 19-21 June 2013).

${ }^{2}$ See ViÑUALES, "Sovereignty in Foreign Investment Law", in DOUGLAS, PAUWELYN and VIÑUALES (eds.), The Foundations of International Investment Law, Oxford, 2014, p. 317 ff.

${ }^{3}$ See Permanent Sovereignty over Natural Resources, UN Doc. A/RES/1803/XVII, 14 December 1962 ("Resolution 1803"); and Armed Activities on the Territory of the Congo (Democratic Republic of the Congo $v$. Uganda), Judgment of 19 December 2005, ICJ Reports, 2005, p. 168, para. 244.

${ }^{4}$ For a contemporary statement of the law on immunities see YANG, State Immunity in International Law, Cambridge, 2012. Three relatively recent cases show the scope of immunities: Arrest Warrant of 11 April 2000 (Democratic Republic of the Congo v. Belgium), Judgment of 14 February 2002, ICJ Reports, 2002, p. 3 ff.; "Ara Libertad" Case (Argentina v. Ghana), Request for the prescription of provisional measures, ITLOS Case No. 20, Order of 15 December 2012; and Jurisdictional Immunities of the State (Germany v. Italy: Greece intervening), Judgment of 3 February 2012, ICJ Reports, 2012, p. 99 ff.

${ }^{5}$ See American Law Institute, Restatement (Second) of the Law of Foreign Relations of the United States, 1965, Section 197(1)(a); American Law Institute, Restatement (Third) of the Law of Foreign Relations of the United States, 1986, Section 712, commentary, letter (g); SOHN and BAXTER, "Draft Convention on the International Legal Responsibility of States for Injuries to Aliens”, AJIL, 1961, p. 545 ff. Relevant cases are identified and discussed later in this article.

${ }^{6}$ Responsibility of States for Internationally Wrongful Acts, GA Res. 56/83, UN Doc. A/Res/ 56/83, 12 December 2001 ("ILC Articles"), Art. 25. Relevant cases are identified and discussed later in this article.

7 See, e.g., SS Wimbledon, PCIJ, Judgment, 17 August 1923, Series A, No. 1, 24-25; SS Lotus, PCIJ, Judgment, 7 September 1927, Series A, No. 10, 18; and Free Zones of Upper Savoy and the District of Gex, PCIJ, Judgment, 7 June 1932, Series A/B, No. 46, 167. 
expression of sovereignty, which was eventually dealt with in the narrower context of expropriation clauses. $^{8}$

The purpose of this article is to draw the attention of commentators and practitioners to the implications, for the expression of sovereignty, of approaching investment regulation through a predominantly treaty-based prism. Disregarding customary international law beyond basic references to the law of treaties or the law of State responsibility amounts indeed to disregarding the main legal concepts expressing the idea of sovereignty. The current trend, noted in the Rapporteur's Report, towards including more regulatory leeway in specific treaty clauses ${ }^{9}$ is not an appropriate solution because it still confines sovereignty to a few exceptions or at best carve-outs instead of recognising that, much in the same way as the necessity defence does not need to be incorporated in a treaty to operate, the same is true of other customary expressions of sovereignty. After a brief discussion of how the interactions between investment treaties and customary international law were framed in the work of the IDI (section 2), I will turn to the analysis of four customary concepts that may operate autonomously and in parallel to investment treaties (section 3). By conducting this exercise, I will attempt to show how excessive emphasis on treaties as a lex specialis may be subtly eroding the room for customary law investment regulation and, thereby, the legitimate expression of sovereignty.

\section{Customary LaW and InVESTMent Regulation IN the IDI ProceEdingS}

The heading of this section uses the conjunction "and" instead of the preposition "in" used in the title of this article to highlight a difference of approach with the work of the IDI. The nuance is easy to understand. Whereas "in" implies that customary law plays or should play a role in investment regulation, "and" has no particular target question and allows for different understandings of the link between customary law and investment regulation. This is only natural for a codification effort such as the one attempted by the IDI, which must endeavour to frame the topic broadly, at least initially. Yet, as I will show in the next paragraphs, the work of the IDI did approach this question broadly at the beginning but as it further refined its contours, the references to sovereignty were increasingly marginalised and eventually lost in the final Resolution. Here, I would like to inverse the order of the analysis by looking first at the Resolution, then at the final Report of the Rapporteur and then to the earlier discussions of the $18^{\text {th }}$ Commission, including those prompted by the questionnaire circulated by the Rapporteur. My analysis will only focus on the link between customary law and investment treaties, and not on the other topics addressed in the IDI's codification work, some of which are covered by other articles in this volume.

The Resolution does not address specifically the relationship between treaty law and customary law. One can find, however, one explicit reference to it in connection with the interpretation and application of treaties "in accordance with the general rules of international law reflected in the Vienna Convention on the Law of Treaties" (Article 1). ${ }^{10}$ It is, of course, a truism to state that the customary rules on treaty law apply to the operation, including the application and interpretation, of (investment) treaties. But, for present purposes, this basic statement has two implications. First, it makes no doubt that the interpretation rules reflected

\footnotetext{
${ }^{8}$ Report, cit. supra note 1, paras. 138-145.

${ }^{9}$ Ibid., para. 3.

${ }^{10}$ Vienna Convention on the Law of Treaties (VCLT), 23 May 1969 (1155 UNTS 331).
} 
by, among others, Article 31(3)(c) of the Vienna Convention, must be applied to interpret investment treaties. Second, and related, among the "relevant rules of international law applicable between the parties" referred to by this interpretation rule one finds all the customary norms expressing the concept of sovereignty in general international law. In other words, at the very least, such norms would "apply" in that they must be taken into account to ascertain de meaning of investment treaty provisions. This is perhaps another truism, but one that has not always been sufficiently integrated in the reasoning of investment tribunals, as I will show with respect to the police powers doctrine. Aside from Article 1, the Resolution mentions "the rights of States to pursue, in a non-discriminatory way, their public and regulatory purposes" (preamble) and the "need for the interpretation and development of the law" as a consideration justifying deviations from a consistent line of precedents (Article 2). None of these references clearly brings customary law to bear but they do highlight the importance of regulatory powers as well as of the need to develop the law on foreign investment regulation even when that requires disregarding a precedent. Overall, the Resolution does not clarify the relations between investment treaties and customary law but it states some principles as obvious, which could hardly be understood otherwise than as assigning some room for customary legal concepts even in the presence of treaties.

Unlike the Resolution, the 2013 Report presented by the Rapporteur to the $18^{\text {th }}$ Commission addressed the relation between investment treaties and customary law explicitly in paragraphs 10 to 27 . This relation is envisaged from two perspectives. The first is introduced by the Rapporteur as follows: "the key and seminal question has been and still is whether the extremely numerous bilateral treaties on the protection of foreign investments, given their substantially homogeneous content, determined the creation of a body of customary international law". ${ }^{11}$

This question is subsequently explored in connection with the alleged emergence of a specialised body of law arising from the decisions of arbitral tribunals or with the appropriate interpretation of investment treaties, particularly by inter-State bodies or by tribunals deciding inter-State disputes. The analysis offered by the Rapporteur only touches upon the topic of this article tangentially, in paragraphs 12 and 13, when discussing the potential emergence of a specialised body of customary investment law:

"[T]he most appropriate - and in any case legally correct - approach appears to be that of the full respect of the different clauses of the various applicable BITs. This is so also because these clauses would necessarily apply, not withstanding any possible differences with the alleged rules of customary law. Actually, the latter can always be derogated, with the limited exception of some procedural and substantive international peremptory norms [...]. When international law is referred to in the interpretation and application of BITs, such reference should be made correctly and appropriately".

These two paragraphs implicitly convey the manner in which the Rapporteur conceives the application of customary law in an investment treaty context. Customary norms may be referred to interpret the treaty (application as interpretation) or as governing norms. In the latter case, they only apply if not derogated by treaty norms (lex specialis), which is, according to the Rapporteur, always possible except for peremptory norms (lex superior). The lex specialis and lex superior hypotheses constitute the second perspective from which the

\footnotetext{
${ }^{11}$ Report, cit. supra note 1, para. 10.
} 
interactions between customary law and investment treaties are approached in the Report. But before moving to this second perspective it is important to note one gap in this analysis, namely that customary norms may intervene also as governing norms for questions not (fully) addressed by investment treaties. Indeed, an investment treaty may include public emergency clauses and, yet, the customary necessity defence will still apply as a customary autonomous defence. Similarly, a treaty may contain a clause reserving environmental regulation and, yet, the police powers doctrine will also apply autonomously as a matter of customary law. This nuance may seem to be a minor point but it is, quite to the contrary, very important for the expression of sovereignty in foreign investment law. Losing sight of this nuance amounts to losing sight of the locus (general and customary) of sovereignty in international law.

The second perspective, discussed in paragraphs 23 to 27 of the Report, frames the interactions between customary law and investment treaties through the lenses of the lex specialis and lex superior principles and, in doing so, it overlooks the aforementioned nuance. Paragraph 27 conveys this point:

"A related problem is whether the alleged autonomy and speciality of BIT's law would be maintained also in the presence of peremptory rules of international law (for instance, the procedural rule of due process, namely the equality of arms, and the substantive rules protecting the environment, human health and fundamental human rights in general, and the State's basic sovereign rights). [...] According to the Rapporteur, leaving aside some difficulties in precisely defining certain rules of jus cogens, the conclusion appears unavoidable that peremptory rules of international law should prevail and/or have precedence over both conventional and customary rules, in the matter of protection of foreign investments" (emphasis added).

If customary norms can only operate as controlling norms for questions already covered by treaty norms, then their application will be conditioned on their higher hierarchy. The Rapporteur refers only to jus cogens in this regard but there may be other forms of lex superior, such as Article 103 of the United Nations Charter. Under this prism, as anticipated by the Rapporteur, the main difficulty will stem from the precise identification of superior norms. However, by placing the debate on this level, much of the expression of sovereignty is lost. There is no need for customary norms expressing sovereignty to be lex superior in respect of investment treaties. Such customary expressions apply together or in addition to treaties, as autonomous concepts specifically addressing questions not (fully) covered by treaties. If, instead, sovereignty were only given room when conveyed by a superior norm, then, the everyday regulatory duties of a State would have little chance of being shielded. As discussed next, during the codification process, some members of the $18^{\text {th }}$ Commission expressed doubt - perhaps justifiably - as to the peremptory character of norms expressing "basic sovereign rights" or protecting objects such as the environment.

After some initial discussions on the scope of the work at the Naples (2009) and Rhodes (2011) sessions of the IDI, the Rapporteur circulated a Questionnaire to prepare a meeting in Rome (June 2013) prior to the Tokyo session (September 2013) where the Resolution was adopted. The Questionnaire offers some useful insights into the materials used by the Rapporteur to prepare his final Report as well as the views expressed by some members of the $18^{\text {th }}$ Commission. Question 2 of the Questionnaire, entitled "The BITs as lex specialis", was formulated as follows: 
“a) Does a BIT, or even a series of BITs, represents a body of rules which are autonomous, as lex specialis, from other rules of general international law, which could not be used for interpreting or filling the possible lacunae of the BIT's regulation?

b) A related point is whether the above autonomy would be maintained also in the presence of peremptory rules of international law (for instance, the procedural rule on the equality of arms, and the substantive rules protecting fundamental human rights and those protecting States' basic economic sovereign rights).

c) An additional related point is whether the autonomy of investment law can be maintained, and/or with what possible qualifications, in the case that the BITs or other international instruments make express reference to international rules".

These questions received differing answers. ${ }^{12}$ Most of them acknowledged that investment treaties do not create an autonomous regulatory regime and that customary international law (e.g., the rules on the interpretation of treaties or, more generally, the law of treaties and general international law) remained applicable. Yet, they also considered that BITs supersede customary norms with which they conflict except for peremptory norms, although the latter have virtually no role to play in investment disputes. On the third question, the answer pointed to the need to take into account other relevant rules for interpretation purposes.

Comparing the questions with the answers is useful to determine at what juncture the understanding of the link between investment treaties and customary norms was framed in a way that excludes the autonomous application of customary concepts expressing sovereignty. The final Report responded, in fact, to this framing and, perhaps inadvertently, left this important question aside. In the following section, I will attempt to go back to the beginning and undertake this legal framing journey again but focusing on the hypothesis left unexplored by the work of the IDI. Given the limited scope of this article, I cannot conduct this inquiry for all or even most legal concepts capable of expressing the idea of sovereignty in foreign investment law. I will therefore limit myself to four basic concepts, namely the police powers doctrine, the necessity defence, countermeasures and transnational public policy.

\section{The Customary Expression of Sovereignty: The Question of Autonomous APPLICATION}

\subsection{The Supplementing Function of Customary Law}

Reference to customary law in investment arbitration is not a particularly controversial question. Tribunals routinely refer to the customary rules on the law of treaties, particularly on treaty interpretation, or to that on State responsibility for internationally wrongful acts. This is hardly surprising and does not call for additional comment. What is, instead, less clear is how exactly this reference operates. Excessive emphasis on treaties as lex specialis may obscure the fact that there are several ways in which customary norms may apply together with investment treaties. In the previous section I mentioned three ways: (i) to interpret treaty provisions; (ii) as governing norms superseding treaty provisions (either because of the lex superior principle or - potentially - as a lex specialis, e.g., if two States have developed a

\footnotetext{
${ }^{12}$ Answers to the questionnaire, in Travaux préparatoires, cit. supra note 1, pp. 25-27.
} 
bilateral custom on the application of a treaty); and (iii) as governing norms supplementing treaty provisions for questions not addressed by the latter. The work of the IDI focused on the first and second categories.

One point of respectful disagreement that I have with the approach followed by the Rapporteur to frame the expression of sovereignty is precisely that such expression was placed under the second category. By doing so, this expression was confined to operating within the narrow and unwelcoming straitjacket of peremptory norms of international law. With the exception of some human rights provisions, it is unclear whether the other considerations identified by the Rapporteur, including "States' basic sovereign rights" would qualify as peremptory norms or otherwise function as lex superior. It is possible that this may be the case, but one would have to target a specific norm and provide a fine-grained analysis of its hierarchy. However, category (ii) is neither the only nor the most suitable approach to understand how customary norms expressing sovereignty may apply. In both theory and practice, category (iii) provides a fuller understanding of the operation of customary norms. As stated by an arbitration tribunal in an award that has become a landmark decision in the development of "treaty" arbitration:

"[I]t should be noted that the Bilateral Investment Treaty is not a self-contained closed legal system limited to provide for substantive material rules of direct applicability, but it has to be envisaged within a wider juridical context in which rules from other sources are integrated through implied incorporation methods, or by direct reference to certain supplementary rules, whether of international law character or of domestic law nature" (emphasis added). ${ }^{13}$

Investment treaties or a specific set of investment norms within a given treaty may indeed operate as a lex specialis displacing customary law. But there are many matters not "specifically" regulated by investment treaties, where customary law continues to apply.

In the quotation above the tribunal refers to "supplementary rules" in order to highlight that such rules come into play as governing norms for matters not addressed in the investment treaty. An obvious example concerns the customary rules on treaty interpretation and application codified in the VCLT, but the supplementing role has a wider scope. As noted by the tribunal in a recent award:

"There are a few essential points to be made in this context. First, the interpretation and application of the BIT is governed by international law, as is any treaty, and the expropriation clause is, obviously, a key part of the BIT. Second, it may not be possible to consider the scope and content of the term 'expropriation' in the BIT without considering customary and general principles of international law, as well as any other sources of international law in this area [...]. The BIT in this case, as in almost all cases, has no definition of 'expropriation' within its text, nor does it contain guidelines that would assist the Tribunal in determining whether or not there has been a compensable taking of property. Expropriation has been and is now part of international law, and the change from dispute resolution under the system of diplomatic protection to investor-state arbitration has not modified that. It is true that BITs have become

${ }^{13}$ Asian Agricultural Products Ltd. v. Republic of Sri Lanka, ICSID Case No. ARB/87/3, Award of 27 June 1990, para. 21 (presided by Dr. A.S. El-Kosheri, a member of the IDI) (“AAPL v. Sri Lanka"). 
the most reliable source of law in this area, as have the awards of ICSID, other investor-state tribunals acting under the UNCITRAL Arbitration Rules, and other modern-day tribunals, such as the Iran-U.S. Claims Tribunal, state practice, and writings of scholars. But that is not inconsistent with the continuing relevance of customary and general principles of international law, at least as to BIT obligations that are silent as to scope and content, as well as any other sources of international law with respect to expropriation" (emphasis added). ${ }^{14}$

An interesting feature of this quotation is that it raises a more general point regarding the supplementary function of customary law. Even if the matter is to some extent addressed in the treaty, one may not automatically conclude that the treaty provisions totally deprive customary law from any form of autonomous application. In the important Nicaragua case ${ }^{15}$ the International Court of Justice (ICJ) stressed that customary and treaty rules (in casu the principles enshrined in Article 2 and 51 of the United Nations Charter) may operate distinctly and autonomously, even when they have similar content. Specifically, incorporation into a treaty does not have the effect of "supplanting" the customary norm (as had been argued by the United States). The importance of this point warrants a reference in extenso to its articulation by the Court:

"[E]ven if the customary norm and the treaty norm were to have exactly the same content, this would not be a reason for the Court to hold that the incorporation of the customary norm into treaty-law must deprive the customary norm of its applicability as distinct from that of the treaty norm [...]. There are a number of reasons for considering that, even if two norms belonging to two sources of international law appear identical in content, and even if the States in question are bound by these rules both on the level of treaty-law and on that of customary international law, these norms retain a separate existence. This is so from the standpoint of their applicability. [...] 178. A State may accept a rule contained in a treaty not simply because it favours the application of the rule itself, but also because the treaty establishes what that State regards as desirable institutions or mechanisms to ensure implementation of the rule [...]. 179. It will therefore be clear that customary international law continues to exist and to apply, separately from international treaty law, even where the two categories of law have an identical content" (emphasis added). ${ }^{16}$

This point is well known to any international lawyer and should normally not call for further discussion. For the purpose of analysing category (iii), this statement is useful to nuance the unqualified references to investment treaties as lex specialis that one finds in legal commentary.

Summarising the foregoing observations, the customary concepts expressing sovereignty are best understood as supplementing investment treaties. This supplementary function is not a subordinated one. Customary norms may address questions on which an

${ }^{14}$ Accession Mezzanine Capital L.P. and Danubius Kereskedohaz Vagyonkezelo v. Hungary, ICSID Case No. ARB/12/3, Decision on Respondents Objection under Arbitration Rule 41(5) of 16 January 2013, paras. 6768.

${ }^{15}$ Military and Paramilitary Activities in and Against Nicaragua (Nicaragua v. United States of America), Merits, Judgment of 27 June 1986, ICJ Reports 1986, p. 14 (“Nicaragua case”), para. 177.

${ }^{16}$ Ibid., paras. 177-179. 
investment treaty is totally or partially silent and, even when the treaty addresses much of a question, this is not to say that the customary norm is fully supplanted. This is important not only because investment treaties barely address the extent of a State's regulatory powers explicitly but also because, when they do so (e.g., through reservations on public emergency or environmental regulatory powers) this is not to be considered as supplanting the customary norms expressing State sovereignty. In the next sections, I will analyse four examples of concepts that I see as customary expressions of sovereignty: the police powers doctrine (3.2); the necessity defence (section 3.3); the doctrine of countermeasures (section 3.4); and the protection of transnational public policy (section 3.5). I will refer to general aspects of these concepts only briefly. My analysis will focus on their operation as customary norms in parallel to investment treaties.

\subsection{The Police Powers Doctrine}

The police powers doctrine is widely recognised by investment arbitration tribunals. Given my own research interests, I have studied its operation mostly in connection with environmental protection, where several cases have recognised and applied this concept to shield regulatory action from investors' claims. ${ }^{17}$ But its scope is, of course, much wider and the practice of investment tribunals provides several examples of cases where this concept has been discussed and sometimes applied to dispose of the claim. ${ }^{18}$

The customary grounding of the police powers doctrine is unanimously recognised in the awards I have mentioned, either explicitly or implicitly (e.g., through a reference to

${ }^{17}$ See, e.g., Técnicas Medioambientales Tecmed S.A. v. United Mexican States, ICSID Case No. $\mathrm{ARB}(\mathrm{AF}) / 00 / 2$, Award of 29 May 2003 ("Tecmed v Mexico"), para. 119 ("[t]he principle that the State's exercise of its sovereign powers within the framework of its police power may cause economic damage to those subject to its powers as administrator without entitling them to any compensation whatsoever is undisputable"); Methanex Corporation v. United States of America, NAFTA (UNCITRAL), Award of 3 August 2005, part IV, Ch. D, para. 7 ("as a matter of general international law, a non-discriminatory regulation for a public purpose, which is enacted in accordance with due process and, which affects, inter alios, a foreign investor or investment is not deemed expropriatory and compensable unless specific commitments had been given by the regulating government to the then putative foreign investor contemplating investment that the government would refrain from such regulation"); Chemtura Corporation (formerly Crompton Corporation) v. Government of Canada, UNCITRAL, Award of 2 August 2010 ("Chemtura v. Canada"), para. 266 ("[T]he Tribunal considers in any event that the measures challenged by the Claimant constituted a valid exercise of the Respondent's police powers. As discussed in detail in connection with Article 1105 of NAFTA, the PMRA took measures within its mandate, in a non-discriminatory manner, motivated by the increasing awareness of the dangers presented by lindane for human health and the environment. A measure adopted under such circumstances is a valid exercise of the State's police powers and, as a result, does not constitute an expropriation").

${ }^{18}$ CME Czech Republic B.V. v. Czech Republic, UNCITRAL, Partial Award of 13 September 2001, para. 603; Marvin Roy Feldman Karpa v. United Mexican States, ICSID Case No. ARB(AF)/99/1, Award of 16 December 2002, paras. 103, 112; Saluka Investments B.V.v. The Czech Republic, UNCITRAL, Partial Award of 17 March 2006 ("Saluka v. Czech Republic"); BG Group Plc. v. Republic of Argentina, UNCITRAL, Award of 24 December 2007, para. 268; AWG Group Ltd. v. Argentine Republic, UNCITRAL, Decision on Liability of 30 July 2010, paras. 149-150; Total S.A. v. Argentine Republic, ICSID Case No. ARB/04/01, Decision on Liability of 27 December 2010, para. 197; Tza Yap Shum v. Republic of Peru, ICSID Case No. ARB/07/6, Award of 7 July 2011, para. 145; El Paso Energy International Company v. Argentine Republic, ICSID Case No. ARB/03/15, Award of 31 October 2011, paras. 236-241, 243; Les Laboratoires Servier, S.A.S., Biofarma, S.A.S., Arts et Techniques du Progres S.A.S. v. Republic of Poland, UNCITRAL, Award (Redacted) of 14 February 2012, paras. 569-570, 584; SAUR International S.A. v. Argentine Republic, ICSID Case No. ARB/04/4, Decision on Jurisdiction and Liability of 6 June 2012, paras. 396-401; TECO Guatemala Holdings, LLC v. Republic of Guatemala, ICSID Case No. ARB/10/23, Award of 19 December 2013, paras. 490-493. 
"general international law" or otherwise). One oft-quoted paragraph recognising this doctrine appears in the award of the arbitration tribunal in the case Saluka v. Czech Republic: "the principle that a State does not commit an expropriation and is thus not liable to pay compensation to a dispossessed alien investor when it adopts general regulations that are 'commonly accepted as within the police powers of States' forms part of customary law today". 19

This reference is useful for a number of reasons. First, as already noted, this authority has been often referred to in subsequent arbitration awards as well as by the IDI in its discussion of expropriation. Second, the reference to the police powers doctrine in this case was not a mere obiter dictum; the doctrine was effectively applied to dispose of the relevant claim. ${ }^{20}$ Third, the award was unanimously rendered by an eminent tribunal, presided by the late Sir Arthur Watts. ${ }^{21}$ Fourth, and perhaps more interestingly for present purposes, the reasoning of the award on the relations between customary law and the applicable investment treaty is ambiguous. It therefore provides a suitable starting-point for the analysis of how the understanding of this relationship may influence the operation of the police powers doctrine.

As previously noted, the police powers doctrine is grounded on customary international law and, as a result, there is no need for it to be explicitly provided for in a treaty. Yet, in the Saluka award, the tribunal seemed to suggest that the doctrine could only be applied if it had been incorporated into the applicable treaty:

"The Tribunal acknowledges that Article 5 of the Treaty [a broad expropriation clause] in the present case is drafted very broadly and does not contain any exception for the exercise of regulatory power. However, in using the concept of deprivation, Article 5 imports into the Treaty the customary international law notion that a deprivation can be justified if it results from the exercise of regulatory actions aimed at the maintenance of public order" (emphasis added). ${ }^{22}$

Taken out of context, this statement would be highly debatable. If the police powers rule has a customary basis, its application does not depend upon a clause incorporating it into the treaty, unless the treaty otherwise excludes it. For a directly relevant and widely recognised customary norm not to apply, there must be a lex specialis clearly excluding its application. However, the tribunal did not address the lex specialis question. Moreover, a relevant customary norm may continue to apply to shape the content of the applicable treaty provision. The tribunal seemed to adhere to this proposition - and therefore lift to some extent the ambiguity of its reasoning - when it referred, in the same paragraph, to Article 31(3)(c) VCLT: "[i]n interpreting a treaty, account has to be taken of 'any relevant rules of international law applicable in the relations between the parties' - a requirement which the International Court of Justice (ICJ) has held includes relevant rules of general customary international law" (emphasis added).

It is, of course, correct that a customary norm may be taken into account to interpret a provision of an investment treaty (a hypothesis that would fall under category (i) of the taxonomy referred to in section 3.1). But the key point is different, namely that there is no

\footnotetext{
${ }^{19}$ Saluka v. Czech Republic, ibid., para. 262.

${ }^{20}$ Ibid., para. 265.

${ }^{21}$ The composition of the tribunal that rendered the award was as follows: Sir Arthur Watts (presiding arbitrator), Yves Fortier (claimant's nomminee), and Prof. Peter Behrens (respondent's nomminee).

${ }^{22}$ Saluka v. Czech Republic, cit. supra note 18, para. 254 (emphasis added).
} 
legal reason to disregard a directly relevant customary norm which has not been specifically excluded by a treaty provision.

In Saluka v. Czech Republic, the tribunal dismissed the expropriation claim brought by the investor. Yet, the ambiguity in its reasoning must be addressed because it is, in fact, quite representative of a conceptually debatable understanding of the relations between custom and treaty. The difference between disregarding a customary norm expressing sovereignty and admitting its autonomous application is indeed not a mere academic point. Recognising such difference is a condition for the customary expression of sovereignty in foreign investment disputes. I have discussed the specific legal implications of this change in perception elsewhere. ${ }^{23}$ My purpose in this article is only to flag this problem drawing the attention of commentators and practitioners to the need to further analyse and give effect to what I have called category (iii) and its wider implications for the expression of sovereignty in foreign investment law.

\subsection{The Customary Necessity Defence}

The customary necessity defence has been raised and, to a varying degree, addressed in several investment arbitration proceedings. ${ }^{24}$ To the extent they effectively address this defence, all these cases recognise the customary nature of the norm codified in Article 25 of the ILC Articles on State Responsibility. ${ }^{25}$ In this respect, they follow the jurisprudence of the ICJ under both the previous and the final version of the ILC Articles. ${ }^{26}$ There is no need to analyse in this article the operation of this defence in general, as this has already been done elsewhere, particularly in connection with the Argentine economic and social crisis of 2001$2003 .{ }^{27}$ As with the police powers doctrine, my main focus will be on the relations between treaty and custom in this context.

${ }^{23}$ See VIÑUALES, cit. supra note 2, pp. 331-343.

${ }^{24}$ See CMS Gas Transmission Company v. Argentina, ICSID Case No. ARB/01/08, Award of 12 May 2005, paras. 316-331 (necessity), 353-378 (emergency clause); CMS Gas Transmission Company v. Argentine Republic, ICSID Case No. ARB/01/08, Decision on Annulment of 25 September 2007, paras. 137-150; $L G \& E$ Energy Corp, LG\&E Capital Corp, LG\&E International Inc. v. Argentine Republic, ICSID Case No. ARB/02/1, Decision on Liability of 3 October 2006, paras. 201-261; Enron and Ponderosa Assets v. Argentine Republic, ICSID Case No. ARB/01/3, Award of 22 May 2007, paras. 314-342; Enron and Ponderosa Assets v. Argentine Republic, ICSID Case No. ARB/01/3, Decision on Annulment of 30 July 2010, paras. 396-417; Sempra Energy v. Argentine Republic, ICSID Case No. ARB/02/16, Award of 28 September 2007, paras. 356-391; Sempra Energy v. Argentine Republic, ICSID Case No. ARB/02/16, Decision on Annulment of 29 June 2010, paras. 159-223; Continental Casualty Company v. Argentine Republic, ICSID Case No. ARB/03/9, Award of 5 September 2008, paras. 160-199, 231-236; Suez, Sociedad General de Aguas de Barcelona S.A. and InterAgua Servicios Integrales del Agua S.A. v. Argentine Republic, ICSID Case No. ARB/03/17, Decision on Liability of 30 July 2010, para. 235-243; and Suez, Sociedad General de Aguas de Barcelona, S.A. and Vivendi Universal, S.A. v. Argentine Republic, ICSID Case No. ARB/03/19, Decision on liability of 31 July 2010, paras. 257-271.

${ }^{25}$ ILC Articles, cit. supra note 6, Art. 25.

${ }^{26}$ Gabčíkovo-Nagymaros Project (Hungary/Slovakia), Judgment of 25 September 1997, ICJ Reports, 1997, p. 7, paras. 50-52; Legal Consequences of the Construction of a Wall in the Occupied Palestinian Territory, Advisory Opinion of 9 July 2004, ICJ Reports, 2004, p. 136, paras. 140-142.

${ }^{27}$ See, e.g., LEBEN, "L'état de nécessité dans le droit international de l'investissement", Les Cahiers de l'arbitrage, 2003, No. 3, p. 47 ff.; ViÑUALES, "State of Necessity and Peremptory Norms in International Investment Law", NAFTA: Law and Business Review of the Americas, 2008, No. 14, p. 79 ff.; BURKE-WHITE and VON STADEN, "Investment Protection in Extraordinary Times: The Interpretation and Application of NonPrecluded Measures Provisions in Bilateral Investment Treaties", Virginia Journal of International Law, 2008, p. 307 ff.; SLOANE, "On the Use and Abuse of Necessity in the Law of State Responsibility", AJIL, 2012, p. $447 \mathrm{ff}$. 
Many of the investment cases assessing the necessity defence (those concerning the USArgentina BIT) had to deal with the combined operation of an emergency clause and the customary necessity defence. A noteworthy feature in this regard was the approach adopted by three tribunals to apply the stringent requirements of the customary necessity defence to assess the availability of a less demanding emergency clause in the applicable investment treaty. ${ }^{28}$ Aside from treating an emergency clause (which excludes some matters from the scope of the treaty) as applicable to the same situation as the necessity defence (which only comes into play once a matter covered by the treaty has been found in breach of a treaty provision), these tribunals disregarded the application of the lex specialis principle. Indeed, assuming that both the treaty clause and the necessity defence would operate to justify what would otherwise is a treaty breach, the former would displace the latter, at least for the matters specifically addressed by the treaty clause.

The starting-point of the analysis must be the first of these three investment disputes, namely $C M S$ v. Argentina, ${ }^{29}$ which influenced the solutions reached in two other cases, Enron v. Argentina ${ }^{30}$ and Sempra v. Argentina. ${ }^{31}$ The $C M S$ award is also useful because, shortly after it was released, another tribunal reached an opposite conclusion in $L G \& E v$. Argentina ${ }^{32}$ on the defences invoked by Argentina. Moreover, in September 2007, an Ad Hoc Committee constituted to review the $C M S$ award severely criticised the reasoning of the tribunal on necessity. ${ }^{33}$ In $C M S$, Argentina argued that the measures challenged by the investor were covered by both the customary necessity defence and Article XI of the Argentina-US BIT (an emergency clause). The tribunal discussed the customary necessity defence first, concluding that it was not available in casu. It then moved to the analysis of the emergency clause in the treaty equating the conditions for its availability with those required by the customary defence. In this context, it noted that, in its review of the treaty clause, it had to "examine whether the state of necessity or emergency meets the conditions laid down by customary international law and the treaty provisions and whether it thus is or is not able to preclude wrongfulness". ${ }^{34}$ This is perhaps the only paragraph of the award where the tribunal explicitly states how it approached the relations between the treaty clause and the customary defence, but there are several other paragraphs in the analysis of the treaty clause where the tribunal specifically addresses customary (not treaty) requirements. By way of illustration, the tribunal notes that it "must determine [...] whether, as discussed in the context of Article 25 of the Articles on State Responsibility, the act in question does not seriously impair an essential interest of the State or States towards which the obligation exists" (para. 357).

Although the tribunal found that this requirement was met, the key consideration is that nothing in the treaty clause calls for the application of this requirement.

An Ad Hoc Committee chaired by the former President of the ICJ, Judge Gilbert Guillaume, was entrusted the mandate to review the award. The Committee severely criticise the reasoning of the arbitral tribunal. On the question of the relations between treaty and custom, the Committee rightly observed: "the requirements under Article XI are not the same

\footnotetext{
See, generally, HeAthCote, State of Necessity and International Law (PhD dissertation, Graduate Institute of International Studies, Geneva, 2005).

${ }^{28}$ CMS v. Argentina, Award, cit. supra note 24, paras. 316-331, 353-378; Enron v. Argentina, Award, cit. supra note 24; and Sempra Energy v. Argentina, Award, cit. supra note 24.

${ }^{29}$ Cit. supra note 24, paras. 316-331, 353-378.

${ }^{30}$ Cit. supra note 24, paras. 314-342.

${ }^{31}$ Cit. supra note 24, paras. 159-223.

${ }^{32}$ Cit. supra note 24, paras. 201-216.

${ }^{33}$ CMS v. Argentina, Decision on Annulment, cit. supra note 24, para. 146.

${ }^{34}$ CMS v. Argentina, cit. supra note 24, para. 374.
} 
as those under customary international law as codified by Article 25, as the Parties in fact recognized during the hearing before the Committee. On that point, the Tribunal made a manifest error of law". 35

From a broader perspective, the errors contained in the CMS award as well as in the two other decisions following this approach (which were subsequently annulled on this point) ${ }^{36}$ raise a more fundamental consideration. If the body of investment treaties form indeed a socalled "self-contained regime" and displace custom with accordance to the lex specialis principle, this reasoning should operate not only to constrain the scope of State sovereignty but also to preserve it when a treaty clause has been expressly included for that purpose.

Even if one were to consider that the CMS tribunal referred to the necessity defence to interpret or supplement a treaty provision (categories (i) and (iii) in the taxonomy introduced in section 3.1), the analysis would still be debatable for at least two reasons. First, the necessity defence was not relevant to interpret the emergency clause because the two norms have different scopes of application. As explained by the Ad Hoc Committee, properly construed as a secondary norm, the necessity defence only intervenes when a breach of an international obligation has been found. But this inquiry presupposes that the measures challenged are not beyond the scope of the treaty as defined, inter alia, by Article XI. If a measure falls under the emergency clause, which the Committee characterised as a "threshold requirement", ${ }^{37}$ then the treaty is not applicable to it and it could not possibly be breached. In turn, there is no breach capable of being justified by the necessity defence. Thus, there is no basis for applying the exacting requirements of the necessity defence (which seek to circumscribe exceptional circumstances under which a breach can be redeemed) to a clause explicitly exempting some measures from the protection granted by the treaty. The second reason why a conflation of the treaty and customary requirements is an error of law concerns the actual contents and operation of customary law. Assuming the emergency clause can be properly characterised as an exception (and not a carve-out, as Article XI), then the requirements of the necessity defence would still not be applicable either as interpretive guidance or as a supplement addressing matters left unaddressed by the clause. This is because applying such more stringent requirements would amount to a restrictive interpretation of a treaty clause that expresses sovereignty, which would be inconsistent with the customary rule that limitations of sovereignty are not to be presumed. ${ }^{38}$ Even if this rule were no longer in force in contemporary international investment law, which is arguable, a conflation of the two norms would still be inconsistent with a neutral interpretation.

As with the police powers doctrine, only through a very debatable line of reasoning (characterising emergency clauses as exceptions, then ignoring the lex specialis principle, then ignoring the presumption against limitations of sovereignty, and then ignoring a neutral interpretation) would it be possible to assert the application of the necessity requirements to an emergency treaty clause. Instead, a proper application of the law would consist in analysing separately the two norms, which target different situations. In this separate application, the customary necessity defence would operate autonomously according to its own requirements.

${ }^{35}$ CMS v. Argentina, Decision on Annulment, cit. supra note 24, para. 130.

${ }^{36}$ Sempra v. Argentina, Decision on Annulment, cit. supra note 24; Enron v. Argentina, Decision on Annulment, cit. supra note 24.

${ }^{37}$ CMS v. Argentina, Decision on Annulment, cit. supra note 24, para. 129.

${ }^{38}$ On the authority of this rule see supra note 7. 


\subsection{The Doctrine of Countermeasures}

Aside from the necessity defence, other customary defences arising from the law on State responsibility for internationally wrongful acts may also have a bearing on investment disputes. One example concerns breaches of international law justified under the doctrine of countermeasures. In at least three cases,${ }^{39}$ this circumstance precluding wrongfulness codified in Article 22 of the ILC Articles was raised in investment arbitration as a potential defence justifying measures with an adverse impact on investors. The three tribunals recognised the customary grounding of the countermeasures defence ${ }^{40}$ and discussed its relationship with the investment protection standards in Chapter 11 of the NAFTA. For present purposes, two main questions must be addressed, namely the extent to which the customary regime on countermeasures may be excluded as a result, on the one hand, of the NAFTA's regulation of countermeasures and, on the other hand, of the nature of investment protection standards.

The first question was discussed in $A D M v$. Mexico in connection with a tax on soft drinks and syrups using any sweeteners other than sugar cane. The claimant, a producer of a sweetener (high fructose corn syrup or HFCS) affected by the measure, argued that the tax was in breach of the protections afforded to investors by Chapter 11 of the NAFTA. The respondent referred, as part of its defence, to the customary regime on countermeasures, arguing that the tax was a legitimate response to a breach of the NAFTA by the United States, the investor's home State. The tribunal analysed the question whether the NAFTA contained a specific regime on countermeasures that would operate as a lex specialis excluding the application of the customary regime. It reasoned that, despite a reference in Article 2019 (Chapter 20) of the NAFTA to countermeasures, Chapter 11 neither authorised nor prohibited the use of countermeasures. As a result, the customary regime on countermeasures remained applicable:

"Chapter Eleven neither provides nor specifically prohibits the use of
countermeasures. Therefore, the question of whether the countermeasures defence
is available to the Respondent is not a question of lex specialis, but of customary
international law [...]. Under customary international law, '[...] the wrongfulness
of an act of a State not in conformity with an international obligation towards
another State is precluded if and to the extent that the act constitutes a
countermeasure [...]' (Article 22 of the ILC Articles). Countermeasures may
constitute a valid defence against a breach of Chapter Eleven insofar as the
Respondent State proves that the measure in question meets each of the conditions
required by customary international law, as applied to the facts of the case [...].
The only instance in which the NAFTA refers to countermeasures is under Article
2019. Under this provision, non-compliance with a decision rendered in a Chapter
Twenty State-to-State arbitration can lead to penalties. In the event of such non-
compliance, the complaining State can retaliate by taking countermeasures
suspending tariff concessions or other obligations under the treaty. Outside Article

${ }^{39}$ Archer Daniels Midland Company and Tate \& Lyle Ingredients Americas, Inc. v. United Mexican States, ICSID Case No. ARB(AF)/04/5, Award of 21 November 2007 (“ADM v. Mexico"); Corn Products International Inc. v. United Mexican States, ICSID Case No. ARB(AF)/04/1, Decision on Responsibility of 15 January 2008 ("Corn Products v. Mexico"); and Cargill, Incorporated v. United Mexican States, ICSID Case No. ARB(AF) $/ 05 / 2$, Award of 18 September 2009 ("Cargill v. Mexico").

${ }^{40}$ ADM v. Mexico, ibid., paras. 125-126; Corn Products v. Mexico, ibid., para. 145; Cargill v. Mexico, ibid., para. 420 . 
2019, the NAFTA makes no express provision for countermeasures. Accordingly, the default regime under customary international law applies to the present situation [...]. The Tribunal therefore agrees with Respondent that countermeasures may serve as a defence under a Chapter Eleven case, as this is a matter not specifically addressed in Chapter Eleven, but valid under customary international law if certain conditions are met" (emphasis added). ${ }^{41}$

Although the tribunal eventually concluded that the requirements for the adoption of countermeasures were not fully met, this case provides a clear illustration of how a customary defence (other than necessity) may perform a supplementary function completing the law applicable to a dispute in the absence of exclusion by the provisions of the relevant treaty.

A different but related question is whether the customary regime on countermeasures would be precluded from operating as a defence against a claim for breach of Chapter 11 because of the nature of the standards provided therein. In two other cases arising from the same tax imposed by Mexico and affecting producers of HFCS, the answer to this question differed from the position of the tribunal in ADM v. Mexico. In Corn Products v. Mexico, the tribunal held that the doctrine of countermeasures concerned inter-State relations and, therefore, could not operate in an investor-State context:

"The Tribunal has concluded, however, that the doctrine of countermeasures, devised in the context of relations between States, is not applicable to claims under Chapter XI of the NAFTA. Those claims are brought by investors, not by States. A central purpose of Chapter XI of the NAFTA was to remove such claims from the inter-State plane and to ensure that investors could assert rights directly against a host State. The Tribunal considers that, in the context of such a claim, there is no room for a defence based upon the alleged wrongdoing not of the claimant but of its State of nationality, which is not a party to the proceedings [...]. The Tribunal therefore concludes that the investor, such as CPI, has rights of its own under Chapter XI of the NAFTA. As such, it is a third party in any dispute between its own State and another NAFTA Party and a countermeasure taken by that other State against the State of nationality of the investor cannot deprive that investor of its rights. To revert to the two different examples given by the ILC in its Commentary on Article 49(1), this is a case involving the rights of a third party and not merely its interests. Mexico owed obligations to CPI under Chapter XI of NAFTA which were separate from the obligations it owed to the United States under the NAFTA as a whole. Even if the doctrine of countermeasures could operate to preclude the wrongfulness of the HFCS tax vis$\grave{a}$-vis the United States (and, for the reasons given below, the Tribunal makes no comment on that question), they cannot do so vis-à-vis CPI' (emphasis added). ${ }^{42}$

The tribunal thus excluded the application of the customary doctrine of countermeasures not because of an argument based on the lex specialis principle but on the basis of the outright inapplicability of the doctrine with respect to third parties, including investors. This is because of the nature of the investment protection standards contained in Chapter 11, which, according to the tribunal, must be treated as "rights". Conversely, the

${ }^{41}$ ADM v. Mexico, cit. supra note 39, paras. 120-123.

${ }^{42}$ Corn Products v. Mexico, cit. supra note 39, paras. 161, 176. 
tribunal admitted that the doctrine of countermeasures could operate to shield the same measures vis-à-vis the United States. One may ask, in this regard, whether a measure affecting foreign investors may under some circumstances be justified by the customary doctrine on countermeasures. The answer depends on how the situation is framed legally. The very same facts triggering an investment dispute may also (or alternatively) give rise to diplomatic protection, in which case the countermeasures defence may be available against the claim of the home State. As noted by the tribunal in Cargill v. Mexico:

"The Tribunal agrees with Respondent that if a State, through diplomatic protection, were to espouse the claims of its nationals damaged by a legitimate countermeasure, then that countermeasure would preclude the wrongfulness of the act that otherwise would have entailed State responsibility and the claims would be denied. In the case of diplomatic espousal, however, the claim is owned by the espousing State and the espousing State is the named party. Moreover, the operative paragraph of the resulting award reciting the decision of the tribunal names the espousing State, and not the national". ${ }^{43}$

Thus, according to Corn Products and Cargill tribunals, depending on whether investment protection standards are characterised as obligations owed to the other contracting State or to its investors, this customary defence would either apply or not. Interestingly, the $A D M$ tribunal referred to the specificity of Chapter 11 for a clearly different purpose, namely to consider that Article 2019 (Chapter 20) could not operate as a lex specialis displacing the customary regime.

The two approaches are not contradictory. Recognising the difference between chapters 11 and 20 may be sufficient to conclude that a provision in Chapter 20 is not a lex specialis for claims under Chapter 11 and, yet, this is not to say that the customary regime is inapplicable to such claims. The question of the nature of investment disciplines is still debated. The distinction between obligations owed to other States and obligations owed to investors may not be a sufficient basis for excluding the operation of the doctrine of countermeasures. It would be difficult to argue that the exceptio non adimplenti contractus, ${ }^{44}$ the synallagmatic character of which is comparable to that of the doctrine of countermeasures, could not suspend the rights of foreign investors. In addition, determining whether a treaty provision provides "rights" to investors should require a more detailed analysis of how the relevant provision is formulated. Thus, the inter-State character of the doctrine of countermeasures does not, of necessity, exclude its operation from investor-State disputes altogether. In all events, this doctrine provides a good example of a matter governed only or mostly by customary law as well as of its potential application as a supplementary norm.

${ }^{43}$ Cargill v. Mexico, cit. supra note 39, para. 424.

${ }^{44}$ Article 60(1) of the VCLT, cit. supra note 10, provides that "[a] material breach of a bilateral treaty by one of the parties entitles the other to invoke the breach as a ground for terminating the treaty or suspending its operation in whole or in part". Paragraph 3(b) of this provision adds that " $t \mathrm{t}]$ he violation of a provision essential to the accomplishment of the object or purpose of the treaty". It is generally recognised that the basic principle underpinning this article is part of general international law, although some details may have to be considered as progressive development. See VILLIGER, Commentary on the 1969 Vienna Convention on the Law of Treaties, Leiden, 2009, p. 730 ff., commentary ad Article 60 (paras. 28-29, stating "[i]n sum, it is doubtful whether Article 60 as a whole is declaratory of customary law. Only para. 1 on bilateral treaties presents a clear and well established picture") and the references to the case law of the ICJ and other authorities referred to therein. 


\subsection{Transnational Public Policy}

The concept of good faith in international law is as vast and difficult to pinpoint as sovereignty itself. ${ }^{45}$ Out of its many legal expressions, some overlap with the expressions of sovereignty. Indeed, a necessary component of sovereignty is the ability of States to ensure the respect of fundamental values and public morals. Profound encroachments on good faith amount to encroachments on ordre public (or public policy) and, more precisely, on the "vital interests $[\ldots]$ of a broader, regional or universal, international community". The latter expression is borrowed from the landmark study of the late Professor Pierre Lalive on what he called "ordre public international" or "transnational public policy". "Lalive characterised this concept by reference to a significant number of domestic precedents:

"From the preceding presentation, which did not attempt to be exhaustive, one thing at least seems clear: in an increasing number of cases, a national judge, although a State organ having the function to state and apply the law of a particular State and to ensure the respect of its fundamental principles (in particular by means of the traditional concept of external public policy) has not hesitated to recognize and give effect to a wider notion, more international or perhaps supranational, of public policy, based on the vital interests not only of the national community to which the judge belongs but also of a broader, regional or universal, international community". ${ }^{47}$

On this basis, he argued that international arbitrators, who do not have a domestic ordre public, should a fortiori recognise a concept of transnational public policy setting fundamental limits on the type of claims and conduct that may be tolerated in international business transactions:

"[I]f judges have not hesitated to accept the idea of transnational public policy, international arbitrators by their very function and, let it be repeated, so to speak a fortiori, (a) could do the same and (b) should be naturally inclined to do the same, in order to reach practical conclusions, either negative (setting aside the normally applicable law or rules), or positive (imperative application, by priority, of certain superior and fundamental norms or principles essential in the law of international trade). In both cases this resort to transnational public policy should aim at protecting certain of the essential values and interests of the international community (of businessmen and States)". 48

Investment arbitration tribunals have also recognised this concept. ${ }^{49}$ In a well-known case against Kenya relating to acts of corruption in securing an investment scheme, the tribunal noted indeed that:

${ }^{45}$ See Kolb, La bonne foi en droit international public. Contribution à l'étude des principes du droit international, Paris, 2000.

${ }^{46}$ LALIVE, "Ordre public transnational (ou réellement international) et arbitrage international”, Revue de l'arbitrage, 1986, p. 329 ff. An English translation of this study appeared as LALIVE, "Transnational (or Truly International) Public Policy and International Arbitration”, ICCA Congress Series, 1987, No. 3, p. 257 ff.

${ }^{4}$ Ibid., para. 97.

48 Ibid., para. 102.

${ }^{49}$ SChreuer, Malintoppi, ReInisch and SinClair, The ICSID Convention: A Commentary, 2 nd ed. Cambridge, 2009, pp. 566-567. 


\begin{abstract}
"The concept of public policy ('ordre public') is rooted in most, if not all, legal systems. Violation of the enforcing State's public policy is grounds for refusing recognition and enforcement of foreign judgments and awards [...]. In this respect, a number of legislatures and courts have decided that a narrow concept of public policy should apply to foreign awards. This narrow concept is often referred as 'international public policy' ('ordre public international'). Although this name suggests that it is in some way a supra-national principle, it is in fact no more than domestic public policy applied to foreign awards and its content and application remains subjective to each State [...]. The term 'international public policy,' however, is sometimes used with another meaning, signifying an international consensus as to universal standards and accepted norms of conduct that must be applied in all fora" (emphasis added). ${ }^{50}$
\end{abstract}

As with the other general international law concepts discussed in previous sections, it is important to clarify the relations between the concept of transnational public policy and investment treaty provisions.

Many investment treaties contain so-called "legality clauses", namely clauses that condition the protection afforded by the treaty to the legality of the investment under domestic law. ${ }^{51}$ The effects of these clauses have received some attention from commentators. ${ }^{52}$ Here, I will only refer to such effects to the extent useful for the analysis of the interaction between legality clauses and the concept of transnational public policy. An important case in this regard is Hamester v. Ghana, where the tribunal made the following statement:
"The Tribunal considers, as was stated for example in Phoenix v. Czech Republic, that: "States cannot be deemed to offer access to the ICSID dispute settlement mechanism to investments not made in good faith'. An investment will not be protected if it has been created in violation of national or international principles of good faith; by way of corruption, fraud, or deceitful conduct; or if its creation itself constitutes a misuse of the system of international investment protection under the ICSID Convention. It will also not be protected if it is made in violation of the host State's law (as elaborated, e.g., by the tribunal in Phoenix) [...]. These are general principles that exist independently of specific language to this effect in the Treaty" (emphasis added). ${ }^{53}$

The operation of these international principles of good faith had already been recognised by other investment tribunals. ${ }^{54}$ What the Hamester tribunal adds is the explicit

${ }^{50}$ World Duty Free Company Limited v. Republic of Kenya, ICSID Case No. ARB/00/7, Award of 4 October 2006, paras. 138-139.

${ }^{51}$ JOUBIN-BRET, "Admission and Establishment in the Context of Investment Protection", in REINISCH (ed.), Standards of Investment Protection, Oxford, 2008, pp. 9-28.

${ }^{52}$ See, e.g., VIÑUALES, Foreign Investment and the Environment in International Law, Cambridge, 2012, pp. 96-100; and DouglAS, "The Plea of Illegality in Investment Treaty Arbitration”, ICSID Review - Foreign Investment Law Journal, 2014, p. $155 \mathrm{ff}$.

${ }^{53}$ Gustav FW Hamester GnbH \& Co KG v. Republic of Ghana, ICSID Case No. ARB/07/24, Award of 18 June 2010, paras. 123-124.

${ }^{54}$ See Europe Cement Investment \& Trade S.A. v. Republic of Turkey, ICSID Case No. ARB(AF)/07/2, Award of 13 August 2009, paras. 174-175; Siag and Clorinda Vechi v. The Arab Republic of Egypt, ICSID 
confirmation that such principles operate autonomously, irrespective of their incorporation into a treaty clause. More specifically, they operate independently from a treaty clause. This observation requires some clarification.

Normally, investment treaties do not refer to transnational public policy. But, as already mentioned, they provide for a legality clause either in the definition of protected investments or elsewhere. Such clauses are broader than the concept of transnational public policy as many situations that are illegal under the law referred to by the clause (normally the domestic law of the host State) would not necessarily be contrary to transnational public policy. However, legality clauses are often formulated to target the "making" of an investment (the so-called "initial" illegality) and not its "operation" (the so-called "subsequent" illegality). Investments made illegally are not protected and a tribunal seized of the matter must reject the claim without proceeding to the merits (either as a matter of jurisdiction or of admissibility). ${ }^{55}$ As for subsequent illegality, it is understood as a defence on the merits of the case. ${ }^{56}$ One question that arises at this point is whether there is any room left for transnational public policy that would not be covered by legality clauses. Aside from the fact that transnational public policy might, in cases where it seeks to protect a value enshrined in a peremptory norm, prevail over treaty clauses, there is also some room for this concept to perform a supplementing function. The highly reprehensible character of the conduct prohibited by transnational public policy calls for the rejection of a claim before reaching the merits (again, whether on jurisdictional or admissibility grounds) even if the illegality arose after the making of the investment. How could one admit that a tribunal may assert jurisdiction to hear a claim relating to an investment vehicle set up in accordance with all the applicable regulations but then operated for human or drug trafficking? This is a hypothesis where the somewhat rigid distinction between initial and subsequent illegality made in connection with legality clauses should be set aside, precisely because the concept of transnational public policy would come into operation.

\section{CONCLUding OBSERVATIONS}

The foregoing observations are only intended to add a word of caution regarding the understanding of the relations between treaty and custom in foreign investment law. My views can be summarised in three main points.

First, there is much more to the relations between customary international law and investment treaties that the debate over so-called "special regimes" or the lex specialis principle. This is something that the Rapporteur clearly highlighted in his Report and questionnaire, although the Resolution did not take a clear position on this debate. The oftquoted reference to the special character of bilateral investment treaties made by in ICJ ruling on preliminary objections in the Diallo case ${ }^{57}$ cannot be considered as endorsing the

Case No. ARB/05/15, Award of 1 June 2009, para. 450; Europe Cement Investment \& Trade S.A. v. Republic of Turkey, ICSID Case No. ARB(AF)/07/2, Award of 13 August 2009, paras. 174-175; Phoenix Action, Ltd. v. Czech Republic, ICSID Case No. ARB/06/5, Award of 15 April 2009, para. 101; Plama Consortium Limited v. Republic of Bulgaria, ICSID Case No. ARB/03/24, Award of 27 August 2008, paras. 138-139; and Inceysa Vallisoletana S.L. v. Republic of El Salvador, ICSID Case No. ARB/03/26, Award of 2 August 2006, para. 230.

${ }_{55}$ On the debate whether this is a matter of jurisdiction or admissibility see DoUGLAS, cit. supra note 52.

${ }^{56}$ Fraport AG Frankfurt Airport Services Worldwide v. Republic of the Philippines, ICSID Case No. ARB/03/25, Award of 16 August 2007, para. 345.

${ }^{57}$ Ahmadou Sadio Diallo (Republic of Guinea v. Democratic Republic of the Congo), Preliminary Objections, Judgment of 24 May 2007, ICJ Reports, 2007, p. 582, para. 88 ("The Court is bound to note that, in 
simplistic view that investment treaties operate a blanket displacement of customary international law. In fact, the very award on which the surge in treaty arbitration is based, namely AAPL v. Sri Lanka, states the opposite view, and the constant references in investment arbitration to the customary rules on the law of treaties or on State responsibility for internationally wrongful acts are a clear confirmation that, in practice, resort to customary international law is both necessary and useful.

Second, the relations between treaty and custom must be elucidated in more detail. A fine-grained chart of this complex topography is required to capture the subtleties of this relationship. The distinction I used in this article between three main ways in which customary norms may apply together with investment treaties - as interpretive tools (category (i)), as governing norms superseding treaty provisions (category (ii)), and as supplementing norms governing questions not covered by treaty provisions (category (iii)) - are only flagged here as a basis for further discussion and refinement. In fact, the travaux préparatoires of the IDI looked into two of them (categories (i) and (ii)) although in less detail than one would have wished. More importantly, I respectfully disagree with the Rapporteur on the way he framed the expression of regulatory powers. A concept as broad and encompassing as sovereignty cannot be adequately accommodated either within a specific investment protection standard (expropriation) or under the abovementioned category (ii). Most of the norms expressing different aspects of sovereignty have no peremptory character and could not prevail over treaty clauses as a lex superior. A key consideration in this regards lies, in my view, in a fuller understanding of category (iii).

Third, as I mentioned in the introduction to this article, most legal or actionable expressions of sovereignty in international law are general in scope (non-branch specific) and customary in nature. Failure to recognise and understand the operation of category (iii) amounts to depriving such legal concepts and, thereby, sovereignty of a proper role in foreign investment law. In my analysis, I identified a number of conceptual ambiguities in the application of concepts such as the police powers doctrine, the customary necessity defence, the doctrine of countermeasures, and the concept of transnational public policy. The operation of these concepts is still debated because many conceptual issues need to be solved. Given the importance of calibrating the legitimate interests of investors with States' rights and duties to regulate, this is an area where more detached and detailed scholarship would be useful. Policy arguments are a major driver for reflexion on an issue such as the proper role of regulatory powers in foreign investment law. But at some point it must give way to a more technical understanding of the actionable concepts expressing sovereignty. Law is a language and, curiously, the political concept of sovereignty is still in need of adequate translation.

\footnotetext{
contemporary international law, the protection of the rights of companies and the rights of their shareholders, and the settlement of the associated disputes, are essentially governed by bilateral or multilateral agreements for the protection of foreign investments [...] and also by contracts between States and foreign investors. In that context, the role of diplomatic protection somewhat faded, as in practice recourse is only made to it in rare cases where treaty régimes do not exist or have proved inoperative"). But the Court adds, in para. 90, that "[t]he fact invoked by Guinea that various international agreements, such as agreements for the promotion and protection of foreign investments and the Washington Convention, have established special legal régimes governing investment protection, or that provisions in this regard are commonly included in contracts entered into directly between States and foreign investors, is not sufficient to show that there has been a change in the customary rules of diplomatic protection; it could equally show the contrary".
} 